United States Department of Agriculture

Agricultural Research Administration

Bureau of Entomology and Plant Quarantine

\title{
NOTES ON LYCTIDAE (COLEOPTERA)
}

By Ross H. Arnett, Jr.

Division of Insect Detection and Identification

That the family Lyctidae, the false powder-post beetles, is of economic importance is indicated by the numerous times these small beetles are encountered in various manufactured goods, such as ax and hammer handles, baskets, and furniture, as well as in buildings and in herbs and roots.

Recently two species, Lyctus prostomoides Gorham and $\underline{L}$. impressa Comolli, have come to my attention as intercepted and imported pests. Although there is no evidence that they have become established in this country, they may have gone unrecognized as "Lyctus sp." Another species $\underline{L}$. villosa Lesne, was sent in for identification recently, and from the data accompanying the specimens, as well as from additional specimens in the U. S. National Museum collection, it appears that this species may have become established in this country, but has not yet been recorded in the literature. Therefore, a few notes on the distinctive appearance of these species, their hosts and distribution, may call attention to their presence in this country, either in existing collections or in those made in the future.

There is some controversy over the proper generic placing of the first two species mentioned above. The current catalog (Lesne 7, pp.14-16) places them in the genus Trogoxylon LeConte ( 5, p. 209). The validity of the separation of this genus from Lyctus Fabricius (2, p. 502) is questionable. LeConte's separation was on the basis of the structure of the anterior tibiae (viz., anterior tibia with the outer apical angle not prolonged in Trogoxylon and prolonged in Lyctus). This character has since been shown not to be constant for the species which LeConte included in the genus. In the original description of the genus the genotype of Trogoxylon was designated as the species Xylotrogus parallelipipedus Melsheimer (8, p. 112). This designation gives us a basis for a definition of the genus. The group that LeConte considered as constituting this genus corresponds roughly to Kraus's (4, pp. 116-118) group of species of Lyctus with confused pubescence and confused or somewhat striate elytral punctation. These species may or may not form a natural group but these 
characters are hardly sufficient for the erection of a separate genus, particularly when the other genera placed in this family are so distinct from the genus Lyctus in the broad sense. Therefore, I prefer to keep the generic name Lyctus in the old sense to include Trogoxylon, at least until more comprehensive work is done and it is demonstrated that other characters, such as those of the larvae and male genitalia, show that further division of Lyctus is necessary.

The following information should help in the recognition of the three species mentioned above and summarizes their distribution. The host data are from specimens in the U.S. National Museum collection.

\section{Lyctus prostomoides Gorham}

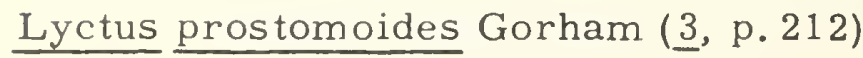

Type locality: El Tumbador, Guatemala.

Size 2.5-5 mm. Color reddish-brown. Head with a prominent double tubercle over the base of the antennae; thorax widest in front, lateral margins nearly straight, anterior and posterior angles acute, punctures moderately large, dense, deeper than those of elytra; outer apical angles of anterior tibiae moderately produced; elytral pubescence confused, moderately long and dense, recumbent, fine, yellow in color, punctures confused, shallow, moderately dense.

This species will key to "Section $\mathrm{a}_{2}$ " in Kraus's key (ㄴ) , but will fit neither alternative in that couplet because the pronotum is broader than long and the pubescence is fine and not bristling and the prosternum is not distinctly punctate throughout.

Hosts: Lacquered tray, wooden crate, dry wood, bamboo, carved wood, basket, furniture, stem of Sambucus sp., and dried herbs.

Distribution and interceptions: Panama: San Lorenzo (Champion); Guatemala: San Geronimo, Purula, El Tumbador (Champion); ? Nicaragua: Chontales (Janson); Mexico: Cordoba (Knab), Jalisco (Diquet), Guanajuato (Sallé), Cuernavaca (via Chicago, Ill.), Guadalajara (via Nogales, Ariz.), "Mexico" (via Brooklyn, N.Y.), "Mexico" (via New York, N.Y.), "Mexico" (via Pittsburgh, Pa.), "Reared from elephant carved from soft African wood purchased from London dealer in Persian goods" (via Rochester, N.Y.).

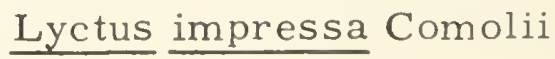

[Lyctus?] [impressa?] Comolli (1, p. 40). (Publication not seen.) 
Size 2.5-5 mm. Color reddish-brown. Head with a prominent double tubercle over the base of the antenna and another prominent, single tubercle over the eye; thorax widest in front, lateral margins nearly straight, anterior and posterior angles acute, pronotum very coarsely and densely punctate, punctures confluent, $\mathrm{Y}$-shaped impression on the disc, the arms of the $\mathrm{Y}$ extending from the anterior margin of the pronotum, at the point where the lateral margins of the head meet the prothorax, to the center of the pronotum, and the base of the Y extending nearly to the posterior margin of the pronotum; elytral pubescence confused, short, sparse, recumbent, fine, yellow in color; punctures on elytra confused, shallow, moderately dense, elytra with variable, vague costae.

This species is included in Kraus's key ().

Hosts: Licorice root, dried roots, chair, umbrella handle.

Distribution and interceptions: "Central Europe, Syria, Barbary Coast [Africa]" (Lesne 7, p. 15); Turkey (via New York, N.Y.); France (via New York, N.Y.); Mississippi (Hopkins, in Kraus 4, p. 130; specimen in U. S. National Museum collection).

\section{Lyctus villosa Lesne}

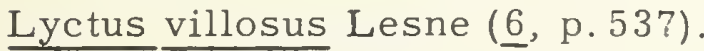

Type locality: Mexico: Zacoalco (Jalisco).

Size 2-3.5 mm. Color reddish-brown. Entire body covered with long, coarse, almost scalelike, semierect hairs which are broadened apically; head without tubercles; thorax quadrate, sides parallel, but slightly sinuate, anterior and posterior angles rounded, surface of pronotum coarsely rugose-punctate, punctures confluent; elytra with pubescence arranged in even, double rows, punctures in serial arrangement between rows of pubescence.

This species will key to Lyctus linearis Goeze in Kraus's key (4, p. 120). L. villosa is separated from L. linearis by the coarse, scalelike pubescence, which is fine and appressed in the latter species.

Hosts: Unidentified wood, furniture, cedar closet, medicinal herbs, "Banak" wood, balsa wood, on banana, wood ceiling in house, woodwork in church, oak flooring, cigar boxes, in Leucaena esculenta (Moc. and Sesse) Benth. (Leguminosae).

Distribution and interceptions: Mexico: Zacoalco, Guadalajara (Jalisco) (via Nogales, Ariz.), "Mexico" (via Binghamton, N. Y.), Monterrey(via Laredo, Tex.), "Mexico"(via Laredo, Tex.), Mexico, D.F. 
Tepic, Nayarit (via Nogales, Ariz.); San Salvador: San Salvador; Costa Rica: "Costa Rica" (via New York, N. Y.); Panama: "Panama" (via New Orleans, La.); Dutch Guiana: "Dutch Guiana" (via Tampa, Fla., and New York, N.Y.); Ecuador: "Ecuador" (via Tampa, Fla.); United States: Redlands, Calif., Clemson College, S. C., Brooklyn, N. Y., Tucson, Ariz.

\section{Literature Cited}

(1) Comolli, A.

1837. De Coleopteris novis ac rarioribus minusve cognitis provinciae Novocomi. 54 pp. Ticini, Fusi. [Publication not seen.

(2) Fabricius, J.

1792. Entomologia systematica. v. 1, 538 pp.

(3) Gorham, H. S.

1883. Malacodermata. Biologia Centrali-Americana. Insecta, Coleoptera. v. 3 , pt. 2,372 pp. 13 pl.

(4) Kraus, E. J.

1911. A revision of the powder-post beetles of the family Lyctidae of the United States and Europe. U.S. Dept. Agr. Bur. Ent. Tech. Ser. No.20, pt. 3, pp. 111-138. Includes appendix by $A$. D. Hopkins, Notes on habits and distribution with list of described species.

(5) LeConte, J. L.

1862. Classification of the Coleoptera of North America, Part I, Smithsn. Inst. Misc. Collect., v. 26, 286 pp.

(6) Lesne, M. P.

1911. Notes sur les Coléoptères Térédiles. [Paris̆] Mus. Natl. d'Hist. Nat. Bul., v. 17, pp. 534-538.

(7)

1938. Bostrychidae. Coleopterorum Catalogus. Pars 161, 84 pp. Berlin.

(8) Melsheimer, F. E.

1846. Descriptions of new species of Coleoptera of the United States. Acad. Nat. Sci. Phila. Proc. 2, pp. 98-118. 